\title{
AGRICULTURE INNOVATION ECOSYSTEM AND FOOD SECURITY: STRATEGY OF ADOPTION OFAGRICULTURE MECHANIZATION IN DEVELOPING COUNTRIES THROUGH "BELT AND ROAD" INITIATIVE CHINA
}

\author{
Epezagne Assamala Ingrid Ruth, Ph.D. candidate Jiangsu University China, in Management \\ Sciences and Engineering, Email:epezagneingrid@yahoo.fr \\ Professor Wenyuan LI, School of Management Jiangsu University China, \\ Email:liwenyuan8@ujs.edu.cn \\ Professor Alex Ariho, AAIN CEO, World Incubation Advisor Board Representative Africa \\ and Visiting Professor in several Universities, Email:alexariho@africaain.org
}

\begin{abstract}
In this article, we study the influence of Agriculture Innovation ecosystem on food security through the contribution of Belt and Road Initiative. We identify strategy which foster agriculture mechanization adoption in developing countries. The innovation ecosystem is the large and diverse range of resources and participants that are necessary and contribute to continuous innovation in an economy. These include investors, entrepreneurs, technical and business development service providers, and researchers amongst others. We engage with agriculture Innovation Ecosystems thinking to consider the ways in which it might enhance efforts to create multi-actor, cross-sectoral innovation that are capable of supporting transitions to sustainable agricultural systems across multiple scale, hence achieving food security (Pigford, Hickey, \& Klerkx, 2018). According to the world health organization (WHO) in the state of food security and nutrition in the world 2018 , new evidence this year corroborates the rise in world hunger observed in this report last year, sending a warning that more action is needed if we aspire to end world hunger and malnutrition in all its forms by 2030 . Through the "belt and road" initiative by the Chinese government, many international students got the opportunity to study in China, and act as a bridge between their respective countries and China (Yu, Qian, \& Liu, 2019). In addition, as home country of great number of manufacturing companies, China promote agriculture mechanization and provide agricultural machinery to belt and road countries (de Soyres, Mulabdic, Murray, Rocha, \& Ruta, 2019). These strategies have an impact in achieving food security worldwide (Zhang, Zhang, Tian, Liu, \& Zhang, 2018). We speak of food security "when all people, at all times, have economic, social and physical access to sufficient, safe and nutritious food that satisfies their nutritional needs and dietary preferences to enable them to live active and healthy lives" stated by Food and Agriculture organization. For this research, we attempted to show how "belt and road" initiative contribute to food security.
\end{abstract}

Keywords: Agriculture Innovation ecosystem, Agricultural mechanization, China, belt and road, food security.

DOI: $10.7176 / \mathrm{IKM} / 11-4-03$

Publication date:May $31^{\text {st }} 2021$ 


\section{Introduction}

Now more than ever the question of food security is one that must be addressed. The agriculture value chain system worldwide encounters many challenges, ranges from access to land and it utilization, post-harvest lost and food waste, use of chemicals and access to machineries. Recent researches underlying agriculture ecosystem identify agricultural innovation as a system which is about people, the knowledge, technology, infrastructure and cultures they have created or learned, who they work with, and what new ideas they are experimenting with. The approach represents a major change in the way that the production of knowledge is viewed, and thus supported. To sustainably meet the increasing demand for food (FAO, 2014, 2016) and achieve food security, agricultural systems will need to transition away from the many common and traditional practices and adopt better management systems (Pigford et al., 2018). To achieve food security, agricultural production should double, significantly surpassing population growth. However, with around 821 million in 2017, compared to around 804 million people hungry in 2016 (UN, 2017) in the world, global food security remains a big challenge. China as a rising economy put in place the «belt and road» initiative in an effort to strengthen international relations and play an active role in solving global issues including hunger which is of the seventeen (17) United Nations (UN) sustainable development goals. This strategy includes promotion of agriculture mechanization and engaging with international talents among other plans. Few decades ago developing region, have seen labor-saving technologies adopted at unprecedented levels. Intensification of production systems created power bottlenecks around the land preparation, harvesting and threshing operations. Alleviating the power bottlenecks with the adoption of mechanical technologies helped enhance agricultural productivity and lowered the unit cost of crop production even in the densely populated countries of Asia, with china as a leading country.

\subsection{China "belt and road" initiative}

Currently, since the "belt and road" of the People republic of china is ongoing, is it challenging to find empirical theory that can systematically show the effect of globalization and food security. Therefore, we rely on current implementation road map of "belt and road", governments' policies, previous research and books in the area of globalization and food security and make a qualitative analysis to deduce the relation between them.

\section{China's Belt and Road Initiative (BRI)}

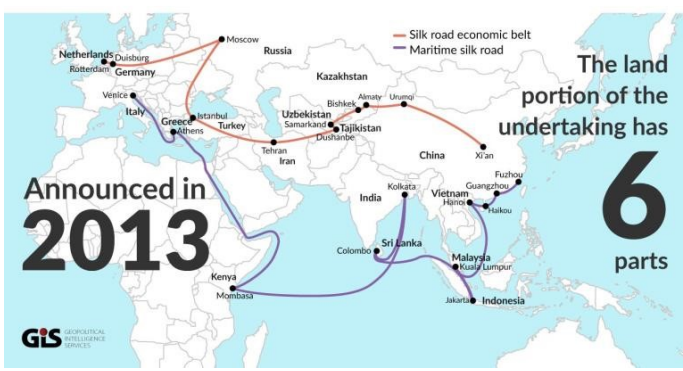

Figure 1 China Belt And Road Initiatives, source of Geopolitical Intelligence Space 
Launched in 2013 as "one belt, one road" initiative (BRI), it involves China underwriting billions of dollars of infrastructure investment in countries along the old Silk Road. The ambition is immense. China is spending roughly $\$ 150$ billion a year in the 68 countries that have signed up to the scheme.

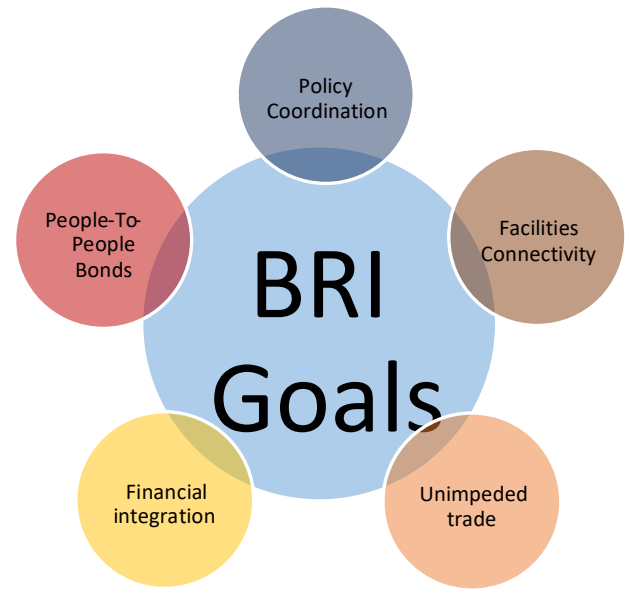

Figure 2 Objectives of Belt and road initiatives of China

In 2018 the initiative has attracted the largest number of foreign dignitaries to Beijing since the Olympic Games in 2008. The BRI is much more than a series of oneoff infrastructure projects. It is a well elaborated project seeking to establish connectivity between Asia, Europe and Africa and in that way to increase trade, development and prosperity. It has five key goals; shown in the diagram below.

\subsection{Agriculture innovation ecosystem}

Transitions to more sustainable agriculture require the formation of innovation niches (Elzen et al., 2012; Meynard et al., 2017). Agriculture innovation ecosystem (Innovation niches) are defined as the spaces that allow actors to experiment, innovate and create new technologies, practices and institutions that can support transitions to sustainable agriculture by enabling interactions across boundaries (e.g. sectoral, organizational, professional, disciplinary, cultural, etc.) in agricultural systems (Elzen et al., 2012; Meynard et al., 2017; Schot and Geels, 2008). They can facilitate the collective action of diverse actors (often in new combinations) for developing new modes of production, new institutional arrangements and new organizational systems to better support systemic learning, adjusting and adapting (Elzen et al., 2012; Meynard et al., 2012; Meynard et al., 2017). In practice, innovation niches can be identified as spaces (i.e. physical, ecological, technological and virtual) where stakeholders come together to define shared objectives and engage in social learning to support an innovation process (Meynard et al., 2017). 


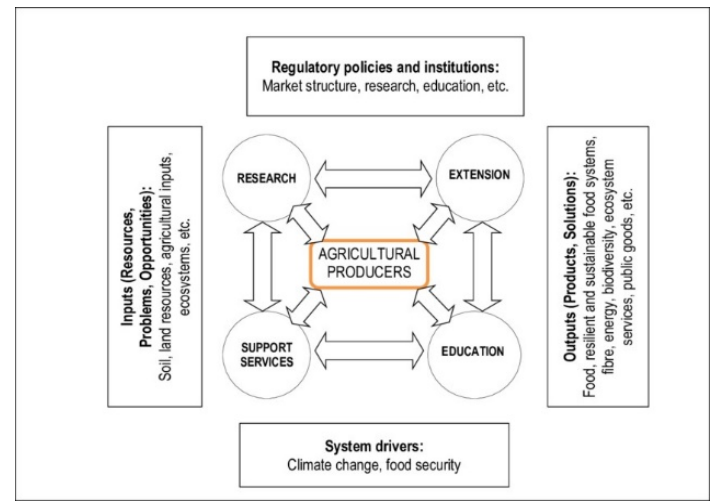

Figure 3 Agriculture innovation ecosystem

Innovation niches are nested within larger regimes (the status quo of dominant systems they aim to change) and socio-technical landscapes (exogenous developments that influence niche development) (Grin et al., 2010; Schot and Geels, 2008; Elzen et al., 2012), but these levels should be seen as analytical constructs because in reality there is no dichotomous struggle between niche and regime, instead transition processes run across multiple scales (e.g. geographic, ecological, technological, etc.) (Ingram, 2015, 2018; Hermans et al., 2016; Svensson and Nikoleris, 2018; de Haan and Rotmans, 2018).

Transitions occur when the creation and broader scaling of innovations established at the innovation niche level interact with current regimes, ideally leading to the opening of existing regimes and transforming them (Hinrichs, 2014; Wigboldus et al., 2016; Ingram, 2018). This perspective implies that agricultural innovation is a process in which co-evolution of technology, practices and institutions takes place at multiple and sometimes overlapping scales (e.g. farm, supply chain, policy system, sector, region, country) (Hermans et al., 2016; Wigboldus et al., 2016). Yet, innovation is not guaranteed, and the mere existence of a niche does not automatically transform a regime, drawing attention to the complex and heterogeneous factors that contribute to entrenched agricultural regimes and lock-in (Ingram, 2015; Wigboldus et al., 2016; Vanloqueren and Baret, 2009). Nonetheless, proponents of sustainability transitions argue that innovation niches can be built to facilitate linkages to support opportunities to innovate in radical ways to help solve complex issues (Geels, 2002; Schot and Geels, 2008), which may also take place through purposeful design (Elzen and Bos, 2016). Thus, there are ongoing questions about the architecture required to support the design and further development of successful agricultural innovation niches (Elzen et al., 2012; Meynard et al., 2017; Prost et al., 2017). The above table shows they share some theoretical foundations and converge on the notion that there is a need to foster innovation environments where scientists, policymakers, producers, end-users and entrepreneurs can mobilize their collective knowledge to innovate (Klerkx et al., 2010; Oksanen and Hautamäki, 2015). 


\begin{tabular}{|c|c|c|}
\hline Historic emergence & $2000 \mathrm{~s}$ & $2000 \mathrm{~s}$ \\
\hline Disciplinary focus & Agriculture & Business and management \\
\hline Theoretical foundations & $\begin{array}{l}\text { National systems of innovation; Technology transfer; Farming systems; Capacit } \\
\text { building; Extension }\end{array}$ & yNational systems of innovation; Business ecosystems; Entrepreneurship \\
\hline System conceptualization & One (sub)sectoral system with embedded systems & System of systems each with embedded systems \\
\hline Focus & Multi-stakeholder processes for problem solving & Multi-stakeholder processes for value co-creation \\
\hline Actors & $\begin{array}{l}\text { Farm-centered: universities, firms, non-profits, decision makers, governmen } \\
\text { institutions, financial markets, farmers; public sector bias }\end{array}$ & $\begin{array}{l}\text { AtFirm-centered: entrepreneurs, universities, firms, non-profits, decision } \\
\text { makers, government institutions, financial markets, end-users, venture } \\
\text { capitalists }\end{array}$ \\
\hline Groups of actors & $\begin{array}{l}\text { Multiple actors; Innovation platforms (also known as hubs and clusters) } \\
\text { Communities of practice; Co-innovation }\end{array}$ & $\begin{array}{l}\text {; Multiple actors in co-operation and competition; Innovation communities } \\
\text { (also known as platforms, hubs and clusters); Co-evolution }\end{array}$ \\
\hline Scale (system boundaries) & Crop; Sector; Region; Country & Local to global; Cut across multiple organizations, functions and industries \\
\hline Level of analysis & $\begin{array}{l}\text { Institutional: Actors and networks and the rules that govern their interaction. } \\
\text { Infrastructural: the physical and knowledge infrastructure involved in innovation }\end{array}$ & $\begin{array}{l}\text { Ecosystem: Integrated system of systems (no actor or system is greater than } \\
\text { another) }\end{array}$ \\
\hline
\end{tabular}

\section{Table 1 Characteristics of agricultural innovation systems and innovation ecosystem}

a Adapted from Foran et al., 2014; Hall, 2007; Klerkx et al., 2012; World Bank, 2012; Schut et al., 2016. b Adapted from de Vasconcelos Gomes et al., 2016, Jackson, 2011; Oh et al., 2016, Oksanen and Hautamäki, 2015

\subsection{Agriculture mechanization and food security foster by the People Republic of China}

Mechanized agriculture is the process of using agricultural machinery to mechanize the work of agriculture, greatly increasing farm worker productivity.

Tractors in use in selected countries ('000 Units)
\begin{tabular}{|l|c|c|c|c|c|c|c|c|c|c|}
\hline Country & 1965 & 1970 & 1975 & 1980 & 1985 & 1990 & 1995 & 2000 & 2005 & 2007 \\
\hline Japan & 60 & 278 & 721.09 & 1471.4 & 1853.6 & 2142.2 & 2123 & 2027.67 & 1910.7 & 1877 \\
\hline China & 73 & 126.4 & 346.8 & 747.9 & 861.4 & 824.1 & 685.2 & 989.1 & 1410.6 & 2063.5 \\
\hline Thailand & 5 & 7 & 7 & 18 & 31.4 & 57.7 & 148.8 & 439.1 & 780 & 830 \\
\hline India & 48 & 100 & 227.7 & 382.9 & 607.8 & 988.1 & 1354.9 & 2091 & 2789 & 3149 \\
\hline Kazakhstan & - & - & - & - & - & - & 170.1 & 52.1 & 44.1 & 40.2 \\
\hline Egypt & 14.5 & 17.3 & 21.5 & 36 & 51.9 & 57 & 89.1 & 86.3 & 98.1 & 102.6 \\
\hline $\begin{array}{l}\text { Côte } \\
\text { d'lvoire }\end{array}$ & 0.7 & 1.4 & 2.2 & 3.7 & 4.3 & 4.8 & 5.3 & 8.4 & 9.3 & 9.4 \\
\hline Nigeria & 1 & 2.9 & 5.7 & 8.4 & 11.1 & 13.9 & 16.7 & 19.4 & 23 & 24.8 \\
\hline Kenya & 5.7 & 7.3 & 6 & 6.5 & 9 & 10 & 11.2 & 12.2 & 13.4 & 14 \\
\hline Tanzania & 16.8 & 17 & 13.6 & 10 & 8 & 7.4 & 7.5 & 16.3 & 21.5 & 21.5 \\
\hline U S A & 4800 & 5270 & 5120 & 4726 & 4670 & 4426.7 & 4344.1 & 4503.6 & 4470.9 & 4389.8 \\
\hline Honduras & 0.4 & 1.7 & 2.8 & 3.3 & 3.9 & 4.5 & 5 & 5.2 & 5.3 & 5.3 \\
\hline Brazil & 114 & 165.9 & 323.1 & 545.2 & 666.3 & 728.8 & 791.2 & 797.5 & 789.6 & 776.9 \\
\hline
\end{tabular}

Source: FAOSTAT-Agriculture website

Table 2 status of agricultural mechanization in some selected countries, source FOASTAT Agriculture website

The disparity is huge between those countries, and we can observe that the productivity of the countries with more machineries are much higher than others and contributes to achieving food security. Beginning in 2003, the Government of Ghana started to reemphasize the importance of mechanization, directly engaged in tractor imports, and established subsidized agricultural mechanization service centers in the last a few years. Several African countries are considering similar mechanization policies. In Nigeria, for example, the government is the primary importer of tractors, which were sold at subsidized prices to farmers (PropCom, 2012). Similarly, the Government of Tanzania has sold more than 5000 sets of imported agricultural machinery at subsidized prices since 2009 (Lyimo, 2011). The government of Mali imported 400 tractors from India in 2006; DRC imported 
920 sets of tractor and farm equipment; and Cameroon planned to import 1000 tractors from India in 2013, all at the subsidized prices (FAO, 2013a). Many of these imports and associated policies are facilitated by lines of credit from the emerging economies such as Brazil, China and India. The records of the Export-Import Bank of India show that Angola, Benin, Burkina Faso, Burundi, Chad, Guinea Bissau and Swaziland have received similar lines of credit ranging from $\$ 4$ million to $\$ 50$ million from India to purchase agricultural machinery (pipeline and operative, as of August 2013). China's exports of agricultural machinery have increased in value from $\$ 410,000$ in 1994 to nearly $\$ 65$ million in 2008, with much of the increase driven by large tractor exports and $11 \%$ of such exports going to Africa (FAO, 2013a). While exports through these credit arrangements with African countries' governments are encouraging these countries to increase agricultural machinery imports, it is a question whether it also presents potential challenges for these countries to be able to establish a private sector-led sustainable supply chain for agricultural mechanization (X. Diao, Cossar, Houssou, \& Kolavalli, 2014).

\section{Research methodology}

Based on the theoretical framework of governments' policies, existing accredited agencies research and scholars work, we conducted this study. In order to gather this data, the main method of research employed was a comprehensive literature review. The study proposes statement is to how innovation ecosystem contribute to food security through belt and road initiative of the people republic of China. Also understand the different strategies used in executing this initiative and analyze their effectiveness. According to the results, the work conducts discussions, mainly including how the following aspect in agriculture mechanization through "belt and road" initiative and agriculture innovation ecosystem lead to the achievement of food security.

\subsection{Purpose of the study}

This research is to analyze and deduce the impact of the "belt and road" initiative on the cause of global food security foster by agriculture mechanization. This study will be guided by three main objectives:

$>$ To understand the "belt and road" initiative of the People republic of China.

$>$ Observe the impact of agriculture innovation ecosystem and food security, identify the advantages and disadvantages if any.

$>$ To analyze the linkages agriculture mechanization and food security in Belt and Road countries as well as the scale and agricultural practices and implications on food security in this part of the world.

\section{2. "Belt and roads" projects}

(Yu et al., 2019) Domestically, China has announced that BRI is a positive enterprise of connectivity driven by a benign nation. Abroad, precisely in the western nations suspicions abound that china's economic situation is driving BRI. (de Soyres et al., 2019) Though views might differ and opinions about can be mitigated, all must acknowledge the positive impact of the undergoing projects on food security. The "belt and road" initiative 
involves reaching out to countries in Africa, Europe, America and other parts of Asia. Some of the majors projects implemented so far are:

\section{Investments}

\begin{tabular}{llllll}
\hline Year & Investor & $\begin{array}{l}\text { Quantity } \\
\text { (\$ million) }\end{array}$ & $\begin{array}{l}\text { Transaction } \\
\text { party }\end{array}$ & Sector & Subsecto \\
\hline 2015 & China General Nuclear & 5960 & Edra & Energy & Electricity \\
\hline 2016 & State Grid & 4490 & CPFL & Energy & Electricity \\
\hline 2016 & Three Gorges & 3660 & $/$ & Energy & Hydro \\
\hline 2013 & Zhejiang Hengyi & 3440 & $/$ & Energy & Oil \\
\hline 2014 & CNPC & 3000 & Refineria del Pacifico & Energy & Oil \\
\hline
\end{tabular}

\section{Construction contracts}

\begin{tabular}{|lllllll|}
\hline Year & Contractor & $\begin{array}{l}\text { Quantity } \\
\text { (\$ million) }\end{array}$ & $\begin{array}{l}\text { Transaction } \\
\text { party }\end{array}$ & Sector & Subsector & Country \\
\hline 2014 & China Railway Construction & 6810 & $/$ & Transport & Rail & Nigeria \\
\hline 2013 & China National Nuclear & 6500 & $/$ & Energy & Nuclear & Pakistan \\
\hline 2015 & China National Nuclear & 4700 & Nucleoeletrica & Energy & Nuclear & Argentina \\
2015 & China Energy Engineering & 3660 & EISA & Energy & Hydro & Argentina \\
\hline 2015 & China Railway Construction & 3510 & $/$ & Transport & Rail & Nigeria \\
\hline Source: The American Enterprise Institute. & & Deloitte Insights | deloitte.com/insights
\end{tabular}

Table 3 source deloitte.com

\section{Discussions}

Agriculture Innovation ecosystem appears to play an important role in achieving food security, as it enables a system where different actors develop their full potential and contribute to the increase of agriculture commodities. In other words, perceiving food security as a policy framework is an example of what James Ferguson (1994) calls "an antipolitical device". Transforming the symptom of poverty, it puts an end to politics. Instead, hunger and poverty by extension must be integrated into the specific economic systems of production, according to the modes of representation and powers in place (George, 1984). In 1996, the World Food Summit made a statement in Rome. Commitment Four states "we will strive to ensure that food and agricultural policies and trade as a whole promote food security for all through a fair and market-oriented global trading system" (ibid.). FAO, 1996). With a dynamic demographics, China's economic growth over the past three decades has been tremendous, making the country largely food self-sufficient. They set the example to use their own equipment to mechanized agriculture and through the belt symptom of poverty, it puts an end to politics. Instead, hunger and poverty by extension must be integrated into the specific economic systems of production, according to the modes of representation and powers in place (George, 1984).

In 1996, the World Food Summit made a statement in Rome. Commitment Four states "we will strive to ensure that food and agricultural policies and trade as a whole promote food security for all through a fair and market-oriented global trading system" (ibid.). FAO, 1996). 
With a dynamic demographics, China's economic growth over the past three decades has been tremendous, making the country largely food self-sufficient. They set the example to use their own equipment to mechanized agriculture and through the belt and road initiative promotes those practices overseas.

\section{Conclusion}

In sum, following the above, innovation ecosystem is a key factor in achieving food security worldwide and the "belt and road" initiation (BRI) enhance this impact. Many cooperation agreements between China and many countries have been signed since the launch of the initiative. The benefits of this cooperation are so far numerous. Innovation Ecosystems thinking may offer a useful umbrella concept that is appropriate for the wider multi functionality of agricultural systems, with the potential to better support economic development worldwide and achieve food security. Through our brief comparison it has become clear that, China "belt and road initiative" is key to Agriculture Innovation Ecosystems through is contribution on mechanization of agriculture worldwide. Agriculture Innovation Ecosystems thinking appears to complement and build on the established foundations achieving food security and to enhance the conceptualization of more sustainable agricultural systems. However, it is still important to be conscious of inflation treats and political instability. Also there is need to for Chinese companies to design agriculture machineries that are more suitable for small size farms. In addition, the mechanization of agriculture is clearly of great significance food security because enable the drastic increase in productivity and eliminate food value along the agriculture value chain. But, manufacturing companies must ensure that the equipment are environmental friendly and are not harmful to human health in the long run.

\section{REFERENCES}

1. Ahmed, A. U. (2004). Assessing the Performance of Conditional Cash Transfer Programs for Girls and Boys in Primary and Secondary Schools in Bangladesh. International Food Policy Research Institute.

2. Ahmed, T., R. Amir, F. Espejo, A. Gelli, and U. Meir. (2007). Food for Education Improves Girls' Education: The Pakistan Girls' Education Programme. Pakistan: World Food Programme.

3. Aksoy, M. A. M. A. A. a. J. C. B. (2005). Global agricultural trade policies. In Global Agricultural Trade and Developing Countries,. 37-54.

4. Andrews, M., Nord, M., Bickel, G., Carlson, S. (1999). Household food security in the United States. Economic Research Service / USDA.

5. Clapp, J. (2015). Food security and contested agricultural trade norms. Journal of International Law and International Relations.

6. Clay, E. (2002). "Food Security: Concepts and Measurement", in Trade Reforms and Food Security: Conceptualizing the Linkages. Food and Agricultural Organization of the United Nations.

7. De Soyres, F., Mulabdic, A., Murray, S., Rocha, N., \& Ruta, M. (2019). How much will the Belt and Road Initiative reduce trade costs? International Economics, 159, 151-164. doi: https://doi.org/10.1016/j.inteco.2019. 07.003 
8. Diao, C., et al. (2012). Mechanization in Ghana. Searching for Sustainable Service Supply Models.

9. Diao, C., et al. (2012). Mechanization in Ghana: Searching for Sustainable Service Supply Models.

10. Diao, X., Cossar, F., Houssou, N., \& Kolavalli, S. (2014). Mechanization in Ghana: Emerging demand, and the search for alternative supply models. Food Policy, 48, 168-181. doi: https://doi.org/10.1016/j.foodpol.201 4.05.013

11. FAO. (1996). Rome Declaration on world food security and world food summit plan of action.

12. Golan E., B. K., Kuchler F. (2002). Traceability for food marketing \& food safety: What's the next step. Agricultural Outlook, 21-25.

13. Griffin, D. (1998). Agricultural globalization: A threat to food security? People's News Agency (PNA) Dispatch.

14. Hirakawa A. R., S. A. M., Cugnasca C. E. (2002). In: Proceedings of the World Congress of Computers in Agriculture and Natural Resources Wireless robust robot for agricultural applications, 414-420.

15. Kent, G. Globalization and food security in Africa.

16. Lang, T. (1996). Food Security: Does it conflict with globalization? Development Journal.

17. Matsuura, K., Iida M., Umeda M., Ono K. (2001). Automatic following vehicle system.

18. Merriman E, B. (2001). Veneman urge Senate leaders to get on track with farm bill, economic stimulus. Capital Press, Friday.

19. Morrison, J. A. P., R. (2000). The Impact of Further Trade Liberalization on the Food Security Situation in Developing Countries.

20. Njinkeu, D. M., A. (2002). Africa and the world trading system: the case of Cameroon. Africa World Press,

21. Noguchi N., R. J. F., Zhang Q., Will J.D., Ishii K. (2001). Development of robot tractor based on RTKGPS and gyroscope. ASAE Annual Meeting.

22. NRC. (1997). Geospatial and Information Technologies in Crop Management. Precision Agriculture in the 21 st Century.

23. P.A, D. (2001). Casting bread upon the water: Comments on technology, globalization and agriculture. J. Agric. Appl. Econ, 33(2), 341-247.

24. Pacific, P. A. t. (1999). Food security versus free trade?

25. Pierce F.J., N. P. (1999). Aspects of precision agriculture. Adv. in Agron., 67, 1-85.

26. Pierce, F. J., and R.P. Cavalieri. (September, 2002). Globalization and Traceability of Agricultural Production: The Role of Mechanization. Agricultural Engineering International: the CIGR Journal of Scientific Research and Development, IV.

27. Pigford, A.-A. E., Hickey, G. M., \& Klerkx, L. (2018). Beyond agricultural innovation systems? Exploring an agricultural innovation ecosystems approach for niche design and development in sustainability transitions. Agricultural Systems, 164, 116-121.doi: https://doi.org/10.1016/j.agsy.2018.04.007

28. Programme), U. U. N. E. (2009). Water security and ecosystem services: the critical connection. 
29. Reid J. F., N. D. G. (2001). Driverless tractors: Automated vehicle navigation becomes reality for production agriculture. 7-8.

30. S.C, B. (2001). Globalization, cropping choices and profitability in American Agriculture. J. Agric. Applied Econ, 33(3), 315-326.

31. Weekly, E. a. P. (2010). Rethinking Agricultural Production Collectivities. 55(9), 64-78.

32. Whitney J.D., M. W. M., Wheaton T.A., Salyani M., Schueller J.K. (1999). Precision farming applications in Florida citrus. Appl. Eng. Agr, 15(5), 399-403.

33. Yu, S., Qian, X., \& Liu, T. (2019). Belt and road initiative and Chinese firms' outward foreign direct investment. Emerging Markets Review, 100629. doi: https://doi.org/10.1016/j.ememar.201 9.100629

34. Zhang, Y., Zhang, J.-H., Tian, Q., Liu, Z.-H., \& Zhang, H.-L. (2018). Virtual water trade of agricultural products: A new perspective to explore the Belt and Road. Science of The Total Environment, 622-623, 988-996. doi: https://doi.org/10.1016/j.scitotenv.20 17.11.351 